\title{
Hubungan Terapi Senam Yoga terhadap Hipertensi pada Lansia
}

\author{
Setiana Andarwulan \\ Email: setianaandarwulan@unipasby.ac.id \\ DIII Kebidanan, Fakultas Sains Kesehatan, Universitas PGRI Adi Buana Surabaya, Indonesia \\ Jl. Dukuh Menanggal XII
}

\begin{abstract}
Abstrak
Hipertensi merupakan salah satu penyakit degeneratif. Penyakit ini biasanya di derita oleh para lansia. Cara pengobatan yang ditempuh dengan melalui penggunaan konsumsi obat penurun tekanan darah, namun mengkonsumsi obat jangka panjang dapat memberikan efek kimi di dalam tubuh, sehingga pemakaian obat - obat yang terbiat dari bahan alam menjadi salah satu obat dalam menurunkan tekana darah. Selain itu yoga juga dapat digunakan dalam menurukan tekanan darah. Dengan mengikuti senam secara rutin. Tujuan dari penelitian adalah mengetahui hubungan antara tekanan darah dengan senam yoga. Metode yang digunakan dalam penelitian adala pre eksperimental, dengan jumlah populasi sebanyak 30 responden, melalui teknik pengambilan sampel yaitu total sampling. Hasil penelitian adalah adanya perbedaan antara uji korelasi senam yoga dan tekanan darah melalui uji chi square didapatkan nilai Asymp. Sig. (2-sided) sebesar 0,025.Terdapat perbedaan yang signifikan antara tekanan darah sebelum dan sesudah melakukan senam yoga.
\end{abstract}

Kata kunci: senam; yoga; hipertensi; lansia.

\begin{abstract}
Hypertension is a degenerative disease. This disease is usually suffered by the elderly. The method of treatment taken is through the use of drug consumption blood pressure lowering drugs, but taking long-term drugs can have a chemical effect in the body, so the use of drugs made from natural ingredients becomes one of the drugs in reducing blood pressure. In addition, yoga can also be used to lower blood pressure. By following exercise regularly. The purpose of this study was to determine the relationship between blood pressure and yoga exercises. The method used in this research is pre-experimental, with a population of 30 respondents, through the sampling technique, namely total sampling. The result of this research is that there is a difference between the correlation test of yoga exercise and blood pressure through the chi square test, the Asymp value is obtained. Sig. (2-sided) 0.025 . There is a significant difference between blood pressure before and after doing yoga exercises.
\end{abstract}

Keywords: gymnastics; yoga; hypertension; the elderly.

\section{Pendahuluan}

Seseorang akan mengalami masa lanjut usia secara bertahap, kemudian mengalami kemunduran, baik fisik, mental dan sosial (1). Masalah yang sangat mendasar pada usia lanjut usia adalah masalah kesehatan yaitu akibat proses degeneratif. Lansia akan mengalami proses degenerasi dan menyebabkan ketidaknyamanan, salah satu permasalahan yang muncul adalah adanya hipertensi dan insomnia (2)(3).

Hipertensi atau tekanan darah tinggi adalah peningkatan tekanan darah sistolik lebih dari $140 \mathrm{mmHg}$ dan tekanan darah diastolik lebih dari $90 \mathrm{mmHg}$ pada dua kali pengukuran dengan selang waktu lima menit dalam keadaan cukup istirahat/tenang. Peningkatan tekanan darah yang berlangsung dalam jangka waktu lama (persisten) 
dapat menimbulkan kerusakan pada ginjal (gagal ginjal), jantung (penyakit jantung koroner) dan otak (menyebabkan stroke) bila tidak dideteksi secara dini dan mendapat pengobatan yang memadai. Banyak pasien hipertensi dengan tekanan darah tidak terkontrol dan jumlahnya terus meningkat. Oleh karena itu, partisipasi semua pihak, baik dokter dari berbagai bidang peminatan hipertensi, pemerintah, swasta maupun masyarakat diperlukan agar hipertensi dapat dikendalikan. ${ }^{(4)}$

Hipertensi pada lansia dapat dicegah atau diobati dengan berbagai cara.Pengobatan terhadap hipertensi antara lain dengan mengkonsumsi obat-obatan, pengaturan pola makan, menghindari stres, menghindari alkohol, tidak merokok ${ }^{(5)}$ Bertambahnya populasi lansia yang tidak dapat dipisahkan dari masalah kesehatan yang dialami oleh lansia. Terjadinya perununan fungsi organ memicu terjadinya berbagai penyakit degeneratif ${ }^{(1)}$. Penyakit degeneratif jurnal ini menimbulkan masalah finasnsial pada negara. Penanganan yang tidak baik dapat menurunkan kualitas hidup lansia. Penurunan tersebut disebabkan makin meningkatnya angka morbiditas yang disebabkan oleh hipertensi. ${ }^{(6)}$ Beberapa penyakit degeneratif yang paling banyak diderita oleh lansia antara lain, gangguan sendi, hipertensi, katarak, stroke, gangguan mental emosional, penyakit jantung dan diabetes melitus ${ }^{(7)}$. Penyakit tersebut temasuk dalam Penyakit Tidak Menular (PTM) adalah penyebab kematian terbanyak di Indonesia. Keadaan dimana penyakit menular masih merupakan masalah kesehatan penting dan dalam waktu bersamaan morbiditas dan mortalitas PTM makin meningkat merupakan beban ganda dalam pelayanan kesehatan, tantangan yang harus dihadapi dalam pembangunan bidang kesehatan di Indonesia. Prevalensi angka kematian akibat PTM meningkat dari $41,7 \%$ pada tahun 1995 menjadi $49,9 \%$ pada tahun 2001 dan 59,5\% pada tahun 2007. Penyebab kematian tertinggi dari seluruh penyebab kematian adalah stroke $(15,4 \%)$, disusul hipertensi, diabetes, kanker, dan penyakit paru obstruktif kronis. Kematian akibat PTM terjadi di perkotaan dan perdesaan $^{(6)(8) \text {. }}$

Olahraga seperti yoga stick mampu mendorong jantung bekerja secara optimal, dimana olahraga mampu meningkatkan kebutuhan energi oleh sel, jaringan dan organ tubuh, dimana akibatnya dapat meningkatkan aliran balik vena sehingga menyebabkan volume sekuncup yang akan langsung meningkatkan curah jantung sehingga menyebabkan tekanan darah arteri meningkat, setelah tekanan darah arteri meningkat akan terlebih dahulu, dampak dari fase ini mampu menurunkan aktivitas pernafasan dan otot rangka yang menyebabkan aktivitas saraf simpatis menurun, setelah itu akan menyebabkan kecepatan denyut jantung menurun, volume sekuncup menurun, vasodilatasi arteriol vena, karena menurunan ini mengakibatkan penurunan curah jantung dan penurunan resistensi perifer total, sehingga terjadinya penurunan tekanan darah ${ }^{(9)(10)(11) .}$

Senam yoga juga menstimulasi pengeluaran hormon endorfin. Endorphin adalah neuropeptide yang dihasilkan tubuh pada saat relaks/tenang. Endorphin dihailkan di otak dan susunan syaraf tulang 
belakang. Hormon ini dapat berfungsi sebagai obat penenang alami yang diproduksi otak yang melahirkan rasa nyaman dan meningkatkan kadar endorphin dalamtubuh untuk mengurangi tekanan darah tinggi. Olahraga terbukti dapat meningkatkan kadar endorphin empat sampai lima kali dalam darah. Sehingga, semakin banyak melakukan senam maka akan semakin tinggi pula kadar b-endorphin. Ketika seseorang melakukan senam, maka b-endorphin akan keluar dan ditangkap oleh reseptor di dalam hipothalamus dan sistem limbik yang berfungsi untuk mengatur emosi. Peningkatan bendorphin terbukti berhubungan erat dengan penurunan rasa nyeri, peningkatan daya ingat, memperbaiki nafsu makan, kemampuan seksual, tekanan darah dan pernafasan. ${ }^{(12,13)}$ Yoga efektif untuk pasien yang menderita hipertensi ringan. Dalam penelitian ini, yoga dilakukan setiap minggu selama 1 jam selama dua bulan. Pada akhir penelitian, para peserta mengalami penurunan tekanan darah. Pada kelompok lain yang berisiko terkena penyakit kardiovaskular, tekanan darah sistolik dan diastolik resting menurun setelah 8 minggu rutin melakukan gerakan yoga. (14,15). Sehingga peneliti tertarik untuk mengetahui hubungan senam yoga dengan hipertensi di kelompok senam yoga.

\section{Metode Penelitian}

Penelitian ini berupa penelitian kuantitatif, dengan menggunakan desain penelitian deskriptif korelasi. Dalam penelitian ini peneliti mencoba menghubungkan antara variabel bebas dengan variabel terikat. Dengan menggunakan desain penelitian pre eksperimen, yaitu bentuk penelitian yang memanipulasi variabel bebas yang ikut dalam memberikan pengaruh pada variabel terikat. Jenis penelitian eksperimen yang diambil adalah one group pre testpost test. Peneliti sebelumnya memberikan pre test kepada kelompok perlakuan. Kemudian peneliti memberikan perlakuan. Setelah selesai peneliti memberikan post test. ${ }^{(16,17)}$.

Populasi dalam kelompok senam ini sebanyak 30 responden. Dengan menggunakan teknik pengambilan sampel total sampling karena jumlah populasi kurang dari seratus $\left({ }^{18)}\right.$ yaitu sebanyak 30 responden.

\section{Hasil Dan Pembahasan}

3.1 Hasil Penelitian

A. Data Tekanan Darah

Tabel 3.1 Deskripsi Data Tekanan Darah Responden Di Kelompok Senam Yoga Asma ( Pre test )

\begin{tabular}{lll}
\hline Tekanan Darah & $\begin{array}{l}\text { Jumlah } \\
\text { Responden }\end{array}$ & Prosentase \\
\hline Sistolik/Diastolik & &
\end{tabular}

\section{Sistolik/Diastolik}

\begin{tabular}{lll}
\hline $140-159 / 90-99$ & 19 & 63,3 \\
\hline $160-179 / 100-109$ & 11 & 36,7 \\
\hline Total & $\mathbf{3 0}$ & $\mathbf{1 0 0}$ \\
\hline
\end{tabular}

Berdasarkan tabel 3.1 diatas menunjukkan bahwa dari 30 responden yang memiliki tekanan darah rentang 140-159/90-99 sebanyak 19 responden (63,3), sedangkan yang memiliki tekanan darah rentang 160-179/ 100-109 sebanyak 11 responden $(36,7 \%)$.

Tabel 3.2 Deskripsi Data Tekanan Darah Responden Di Kelompok Senam Yoga Asma ( Pre test)

\begin{tabular}{lcc}
\hline Tekanan Darah & $\begin{array}{l}\text { Jumlah } \\
\text { Responden }\end{array}$ & Prosentase \\
\hline Sistolik/Diastolik & & \\
\hline $130-139 / 85-89$ & 9 & 30 \\
\hline $140-159 / 90-99$ & 15 & 50 \\
\hline $160-179 / 100-109$ & 6 & 20 \\
\hline Total & $\mathbf{3 0}$ & $\mathbf{1 0 0}$ \\
\hline
\end{tabular}


Jurnal Kebidanan Harapan Ibu Pekalongan

Berdasarkan tabel 3.2 diatas menunjukkan bahwa dari 30 responden yang memiliki tekanan darah rentang 130-139/85-89 sebanyak 9 responden $(30 \%)$, yang memiliki rentang 140-159/90-99 sebanyak 15 responden (50\%), sedangkan yang memiliki tekanan darah rentang 160-179/ 100-109 sebanyak 6 responden $(20 \%)$

\section{B. Tabulasi Silang}

Tabel 3.3 tabulasi silang senam yoga dan tekanan darah.

\begin{tabular}{|c|c|c|c|c|c|c|}
\hline \multirow{3}{*}{ Senam } & \multicolumn{4}{|c|}{ Tekanan Darah } & \multirow{2}{*}{\multicolumn{2}{|c|}{ Total }} \\
\hline & \multicolumn{2}{|c|}{ Menurun } & \multicolumn{2}{|c|}{ Tetap } & & \\
\hline & $\mathbf{N}$ & $\%$ & $\mathbf{N}$ & $\%$ & $\mathbf{N}$ & $\%$ \\
\hline $\begin{array}{l}\text { Melakukan } \\
\text { tdk sesuai }\end{array}$ & 6 & 42,8 & 6 & 37,5 & 12 & 40 \\
\hline $\begin{array}{l}\text { Melakukan } \\
\text { sesuai }\end{array}$ & 8 & 57,2 & 10 & 62,5 & 18 & 60 \\
\hline Total & 14 & 100 & 16 & 100 & 30 & 100 \\
\hline
\end{tabular}

Berdasarkan tabel 3.3 diatas menunjukkan dari 30 responden yang tekanan darahnya menurun sebanyak 8 responden $(57,2 \%)$ dengan melaksanakan teknik senam yoga secara sesuai, 6 responden $(42,8 \%)$ melaksanakan teknik senam yoga yang kurang sesuai. Sedangkan responden yang tekanan darahnya tetap sebanyak 10 responden $(62,5 \%)$ yang melakukan teknik senam yoga secara sesuai dan 6 responden $(37,5 \%)$ dengan melaksanakan teknik senam yoga secara kurang sesuai.

\section{Uji Korelasi}

Tabel 3.4 Uji Korelasi Senam Yoga dan Tekanan Darah

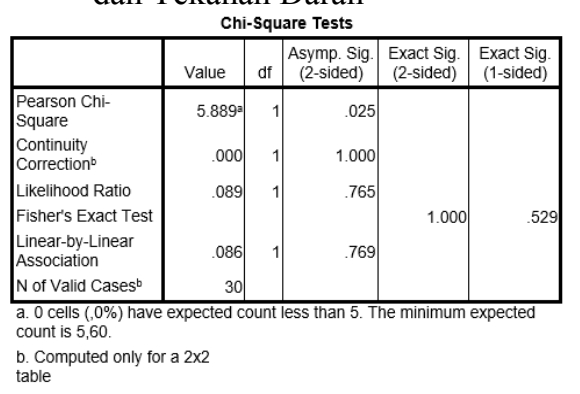

Berdasarkan tabel 3.4 menunjukkan bahwa uji korelasi senam yoga dan tekanan darah melalui uji chi square didapatkan nilai Asymp. Sig. (2-sided) sebesar 0,025 .

\subsection{Pembahasan}

Berdasarkan hasil penelitian yang dilakukan pada 30 responden yang tekanan darahnya menurun sebanyak 8 responden $(57,2 \%)$ dengan melaksanakan teknik senam yoga secara sesuai, 6 responden (42,8\%) melaksanakan teknik senam yoga yang kurang sesuai. Sedangkan responden yang tekanan darahnya tetap sebanyak 10 responden $(62,5 \%)$ yang melakukan teknik senam yoga secara sesuai dan 6 responden (37,5\%) Dengan melaksanakan teknik senam yoga secara kurang sesuai. Selain itu uji korelasi menunjukkan Asymp. Sig. (2-sided) sebesar 0,025. Nilai tersebut lebih kecil dari alpha 0,05 .

Terdapat perbedaan yang signifikan antara tekanan darah sebelum dan sesudah melakukan senam yoga. Sehingga dapat disimpulkan bahwa terdapat pengaruh senam yoga terhadap tekanan darah lansia yang mengalami hipertensi.Hasil yang didukung oleh penelitian Pangaribuan \& Bewari (2016) tentang pengaruh senam yoga, jantung, senam lansia dan aerobik dalam menurunkan tekanan darah pada Hasil penelitian lansia diperoleh bahwa senam teratur dapat menurunkan nilai tekanan darah pada lansia yang masuk dalam kategori hipertensi ${ }^{(19) .}$

Hal ini juga sejalan dengan penelitian Wolff et.al., (2013) tentang dampak yoga tentang tekanan darah dan kualitas hidup penderita hipertensi. ${ }^{(10)}$ Penelitian yang sama juga dilakukan Kinasih 
(2010) tentang pengaruh latihan yoga terhadap peningkatan kualitas hidup. Hasil penelitian menunjukkan bahwa senam yoga berpengaruh terhadap fisik, psikis dan spiritual, sedangkan Dinata (2015) dalam penelitiannya tentang cara menurunkan tekanan darah pada lansia melalui senam yoga menyimpulkan bahwa setiap bagian dari latihan yoga mempunyai manfaat yang baik bagi tubuh. Khususnya untuk menurunkan tekanan darah, maka yoga sangat dianjurkan pada penderita tekanan darah tinggi. (20)(21).

Hal yang sama diungkapkan oleh Hagins et al., (2013) dalam penelitiannya tentang Efektifitas Yoga untuk Hipertensi menunjukkan bahwa Yoga mempunyai pengaruh yang sederhana namun signifikan.pada tekanan darah sistolik dengan nilai $\mathrm{p}$ $=0,0002$ dan tekanan darah diastolik dengan $\mathrm{p}=0,0001)$. Penelitian ini juga didukung oleh teori Marchanda \& Madan (2015) yang menyatakan bahwa yoga secara teratur dapat menurunkan hormon stres 'aldosteron' yang merupakan vaskonstriksi yang kuat untuk meningkatkan tekanan darah. Latihan rutin dapat mengurangi 'vasopresin' hormon stres lain yang disekresikan oleh kelenjar pituitari di otak yang dapat meningkatkan vasopresin melalui e kontraksi pembuluh darah. Yoga dianjurkan pada penderita hipertensi, karena yoga memiliki efek relaksasi yang dapat melancarkan peredaran darah ke seluruh tubuh. Sirkulasi darah yang lancar menandakan kerja jantung yang baik (Marchanda \& Madan, 2015) ${ }^{(11)}$.

Dari hasil penelitian dan penelitian diatas peneliti menganalisa bahwa senam yoga memang memiliki hubungan atau dapat mempengaruhi tekanan darah seseorang. Hal tersebut telah dibuktikan oleh peneliti dan juga peneliti sebelumnya. Namun ada juga beberapa penelitian yang hasilnya tidak berhubungan, mungkin karena faktor responden, waktu yang salah atau tidak tepat dan kemungkinan karena teknik yang tidak tepat. Karena untuk mendapatkan hasil yang baik maka seseorang juga harus melakukan senam yoga secara teratur, tepat waktu pelaksanaannya persis bagaimana melakukannya, maka seseorang harus melakukan senam yoga dengan sungguh-sungguh karena dalam melakukan senam yoga seseorang harus memfokuskan pikirannya. Seperti kita ketahui bahwa tekanan darah akan normal jika pikiran seseorang sedang tenang, maka senam yoga dilakukan dengan pikiran yang tenang dan niatnya datang dari dirinya sendiri bukan paksaan dari orang lain.

\section{Kesimpulan}

Berdasarkan hasil penelitian dapat disimpulkan bahwa sebelum latihan yoga terdapat separuh responden dengan tekanan darah sistolik berada pada skala hipertensi sedang dan tekanan darah diastolik berada pada skala hipertensi ringan sedangkan setelah melakukan senam yoga terdapat separuh responden dengan tekanan darah sistolik dalam skala besar. skala hipertensi ringan dan diastoliknya berada pada skala hipertensi ringan. Dari hasil uji statistik ditemukan perbedaan yang signifikan antara tekanan darah sebelum dan sesudah melakukan senam yoga, sehingga dapat disimpulkan bahwa terdapat pengaruh senam yoga terhadap tekanan darah pada lansia yang mengalami hipertensi.Untuk itu, program senam yoga dapat dijadikan 
Jurnal Kebidanan Harapan Ibu Pekalongan

salah satu program utama untuk lansia.

\section{Daftar Pustaka}

[1]. Azizah LM. Keperawatan Lanjut Usia. Yogyakarta: Graha Ilmu, 2011. 2011.

[2]. Awang D. Mosby's Handbook of Herbs and Natural Supplements. Focus Altern Complement Ther. 2011;

[3]. Chasanah N, Supratman S. Hubungan Kualitas Tidur Dengan Kualitas Hidup Pada Lansia Di Surakarta. J Ber Ilmu Keperawatan. 2018;

[4]. Kemenkes.RI. Pusdatin Hipertensi. Infodatin. 2014;

[5]. World Health Organization. WHO | Raised blood pressure. World Health Organization. 2011.

[6]. Depkes RI. Bersama Selesaikan Masalah Kesehatan. Kementeri Kesehat RI. 2018;

[7]. Badan Penelitian dan Pengembangan Kesehatan. Riset Kesehatan Dasar 2013. Ris Kesehat Dasar 2013. 2013;

[8]. Depkes RI. Hipertensi Penyakit Paling Banyak Diidap Masyarakat. Kementerian Kesehatan RI. Sekretariat r Jenderal. Rencana Strategis Kementerian Kesehatan Tahun Rencana Strategis Kementerian Kesehatan Tahun. 2019.
[9]. Park SH, Han KS. Blood pressure response to meditation and yoga: A systematic review and metaanalysis. Journal of Alternative and Complementary Medicine. 2017.

[10]. Wolff M, Sundquist K, Larsson Lönn S, Midlöv P. Impact of yoga on blood pressure and quality of life in patients with hypertension - a controlled trial in primary care, matched for systolic blood pressure. BMC Cardiovasc Disord. 2013;

[11]. Hagins M, States R, Selfe T, Innes K. Effectiveness of yoga for hypertension: Systematic review and metaanalysis. Evidence-based Complement Altern Med. 2013;

[12]. Lestari P, Putri RA. KOMBINASI SELF HYPNOSIS DAN SENAM YOGA TERHADAP TINGKAT NYERI DAN KECEMASAN SAAT MENSTRUASI. Indones $\mathrm{J}$ Midwifery. 2018;

[13]. Anwari M, Vidyawati R, Salamah R, Refani M, Winingsih N, Yoga D, et al. PENGARUH SENAM ANTI HIPERTENSI LANSIA TERHADAP PENURUNAN TEKANAN DARAH LANSIA DI DESA KEMUNINGSARI LOR KECAMATAN PANTI KABUPATEN JEMBER. Indones J Heal Sci. 2018;

[14]. Field T. Yoga clinical research review. Complement Ther Clin Pract. 2011; 
Jurnal Kebidanan Harapan Ibu Pekalongan

[15]. Damodaran A, Malathi A, Patil N, Shah N, Suryavanshi, Marathe S. Therapeutic potential of yoga practices in modifying cardiovascular risk profile in middle aged men and women. J Assoc Physicians India. 2002;

[16]. Sastroasmoro S, Ismael S. Studi cross-sectional. In: Dasar-dasar Metodologi Penelitian Klinis. 2013.

[17]. Sugiyono PD. metode penelitian kuantitatif, kualitatif,dan R\&D. Alfabeta, cv. 2016.

[18]. Sujarweni VW. Metodologi Penelitian. Jakarta: Rineka Cipta. 2015.

[19]. Pangaribuan BBP, Berawi K. Pengaruh SenamJantung, Yoga, Senam Lansia,dan Senam Aerobik dalam Penurunan Tekanan Darah pada Lanjut Usia. Majority. 2016;

[20]. Dinata W. MENURUNKAN TEKANAN DARAH PADA LANSIAMELALUI SENAM YOGA. J Olahraga Prestasi. 2015;

[21]. Setiawan IWA, Yunani, Eni K. Hubungan Frekuensi Senam Lansia Terhadap Tekanan Darah dan Nadi pada Lansia Hipertensi. Pros Konf Nas II PPNI Jawa Teng 2014. 2014; 